\title{
ANALISIS ADMINISTRASI KURIKULUM PADA SEKOLAH MENENGAH ATAS SWASTA TUNAS BARU CIPARAY
}

\author{
Asti Putri Kartiwi \\ Universitas Muhammadiyah Sukabumi, Jl. R. Syamsudin No. 50 Kota Sukabumi, \\ astiputri414@ummi.ac.id
}

\begin{abstract}
ABSTRAK
Kurikulum dipandang sebagai suatu program yang didisain, direncanakan, dikembangkan, dan akan dilaksanakan dalam situasi belajar mengajar yang sengaja diciptakan di sekolah. Berdasarkan pengamatan yang penulis lakukan, penulis mendapati bahwa proses belajar mengajar di SMA Tunas Baru Ciparay belum berjalan dengan baik diakibatkan oleh administrasi kurikulum yang belum berjalan sebagaimana mestinya. sebagai berikut: (1) Penyusunan jadwal yang sering diubah yang disebabkan karena banyak guru yang mengajar di tempat lain. Pihak sekolah harus menyesuaikan jadwal para guru terutama mereka yang mengajar di sekolah lain.; (2) tingkat absensi guru dan siswa cukup tinggi ; (3) guru jarang membuat perangkat pembelajaran karena kepala sekolah jarang memeriksanya;(4) Penempatan guru yang tidak tepat, banyak guru yang mengajar di luar bidang kemampuannya. Dari keempat permasalahan diatas dapat disimpulkan bahwa inti permasalahan pada SMA Swasta Tunas Baru Ciparay terletak pada kelemahan kepala sekolah dalam melaksanakan fungsinya. Rekomendasi kepada Kepala Sekolah sebagi pelaksana kurikulum disekolah sebaiknya mengambil tindakan: (1) Memberikan teladan yang baik bagi guru dan staf dalam hal kedisiplinan;(2) memberikan sanksi bagi guru yang kurang disiplin.; (3) memberikan apresiasi/reward bagi guru yang disiplin; (4) memberikan pembinaan bagi para guru baik secara formal maupun informal; dan (5) menempatkan guru dan staf sesuai dengan kemampuannya (the right man in the right place).
\end{abstract}

\section{Kata kunci: Administrasi, Kurikulum, Kepala Sekolah}

\section{PENDAHULUAN}

Kurikulum berkaitan dengan sesuatu yang dijadikan pedoman dalam segala kegiatan pendidikan yang dilakukan, termasuk kegiatan belajar mengajar di kelas. Dalam hal ini kurikulum dipandang sebagai suatu program yang didisain, direncanakan, dikembangkan, dan akan dilaksanakan dalam situasi belajar mengajar yang sengaja diciptakan di sekolah. Sebagai suatu program pendidikan untuk mencapai sejumlah tujuan pendidikan tertentu, kurikulum perlu dikelola agar segala kegiatan pendidikan menjadi lebih produktif. Pengelolaan kurikulum yang tidak diarahkan dengan baik akan membuat proses pembelajaran di SMA Tunas Baru Ciparay belum berjalan dengan baik. Berdasarkan pengamatan yang penulis lakukan, penulis mendapati bahwa proses belajar mengajar di SMA Tunas Baru Ciparay belum berjalan dengan baik diakibatkan oleh administrasi kurikulum yang belum berjalan sebagaimana mestinya. Karena itulah Penulis memutuskan 
untuk melakukan analitis kritis terhadap pelaksanaan administrasi kurikulum di sekolah tersebut.

\section{PEMBAHASAN}

Kurikulum adalah seperangkat rencana dan pengaturan, mengenai tujuan, isi, dan bahan pelajaran serta cara yang digunakan sebagai pedoman penyelenggaraan kegiatan pembelajaran untuk mencapai tujuan pendidikan tertentu (Sanjaya, 2008, Prihantoro, 2015). Kurikulum disusun oleh satuan pendidikan untuk memungkinkan penyesuaian program pendidikan dengan kebutuhan dan potensi yang ada di daerah.

\section{Hakikat Pembinaan Kurikulum di Sekolah}

Secara sederhana pembinaan kurikulum adalah upaya yang dilakukan oleh tenaga kependidikan untuk menjaga dan mempertahankan agar kurikulum tetap berjalan sebagaimana seharusnya (Tyler, 2013). Tenaga kependidikan yang dimaksud meliputi Kepala Sekolah, guru, tenaga bukan guru (pembimbing dan lain-lain). Sedangkan kurikulum yang dimaksud adalah kurikulum potensial yakni semua program pendidikan dan ketentuan-ketentuan yang telah digariskan. Pembinaan kurikulum penting mengingat dalam pelaksanaan kurikulum tidak mustahil dihadapkan dengan sejumlah kendala yang mengakibatkan apa yang dilaksanakan secara nyata tidak sesuai dengan apa yang seharusnya. Artinya terdapat perbedaan atau kesenjangan antara yang dilaksanakan dengan yang seharusnya dilaksanakan. Kendala tersebut misalnya kemampuan guru, terbatasnya fasilitas belajar, lemahnya pengelolaan sekolah, belum efektifnya bimbingan penyuluhan, dan lain-lain. (Hamalik, 1995)

Sejalan dengan makna pembinaan di atas maka tujuan pembinaan kurikulum adalah diperolehnya pelaksanaan kurikulum yang mantap. Dapat pula dikatakan bahwa tujuan pembinaan kurikulum adalah memperkecil atau meniadakan kesenjangan antara apa yang seharusnya dilaksanakan dengan apa yang dapat dilaksanakan (Tim Dosen, 2007).

Sebagai contoh yang sederhana, menurut ketentuan yang digariskan dalam kurikulum satu semester sekurang-kurangnya terdiri atas 18 pertemuan tatap muka di kelas. Mengingat banyaknya hambatan, kenyataannya hanya dapat dilakukan 12 pertemuan. Ini berarti ada kesenjangan 6 pertemuan. Kasus ini termasuk pelaksanaan kurikulum tidak mantap. Pembinaan harus dilakukan, yakni menambah pertemuan tatap muka sebanyak enam kali lagi sebelum diberikan ujian. Apabila dipaksakan memberikan 
ujian, padahal materi belum selesai mengakibatkan kualitas siswa menjadi turun/rendah sebab mereka tidak mencapai apa yang seharusnya dicapai.

Menjaga dan mempertahankan pelaksanaan kurikulum agar sesuai dengan tuntutan dan ketentuan yang telah ditetapkan dalam kurikulum potensial menjadi tugas dan tanggung jawab semua aparat pendidikan, seperti para pengawas, kepala sekolah, guru, dan tenaga kependidikan lainnya. Namun demikian upaya pembinaan kurikulum yang paling langsung adalah kepala sekolah dan guru (Tim Dosen, 2007).

\section{Ruang Lingkup Pembinaan Kurikulum}

Ruang lingkup pembinaan kurikulum di lembaga pendidikan atau sekolah mencakup semua komponen kurikulum terutama yang mempengaruhi anak didik. Adanya peran dan posisi yang berbeda antara Kepala Sekolah dengan guru, maka ruang lingkup pembinaan kurikulum dapat dibedakan menjadi dua kategori, yakni pembinaan oleh Kepala Sekolah dan pembinaan oleh guru.

\section{Lingkup Pembinaan oleh Kepala Sekolah}

Kepala sekolah adalah penanggung jawab pelaksanaan kurikulum di sekolah yang dipimpinnya. Sehubungan dengan itu maka peranan Kepala Sekolah tidak hanya berperan sebagai pembina kurikulum tetapi juga menjadi koordinator pembinaan kurikulum.(Hamalik, 1995) Lingkup pembinaan yang menjadi tanggung jawab Kepala Sekolah antara lain:

1. Pencapaian tujuan lembaga pendidikan/sekolah.

2. Efektivitas dan efisiensi strategi pelaksanaan kurikulum.

3. Efektivitas dan efisiensi penggunaan sarana kurikuler.

4. Menilai keberhasilan upaya pembinaan kurikulum, yang dilaksanakan staf.

\section{Lingkup Pembinaan oleh Guru}

Ruang lingkup pembinaan kurikulum oleh guru mencakup antara lain:

1. Proses belajar mengajar atau hasil belajar

2. Pelaksanaan bimbingan penyuluhan

3. Pembinaan administrasi sekolah

4. Pembinaan pribadi (Cropley and Dave, 2014; Farisi, 2011)

\section{Peranan Kepala Sekolah dalam Pembinaan Kurikulum}

Peranan kepala sekolah dalam pembinaan kurikulum sangat menentukan keberhasilan penyelenggaraan pendidikan di sekolahnya. Bahkan dapat dikatakan Kepala Sekolah bertanggung jawab penuh terhadap penyelenggaraan pendidikan di sekolah. 
Pendidikan dikatakan berjalan apabila kurikulum potensial dilaksanakan di sekolah oleh semua staf, dan siswa yang terlibat di dalamnya.(Ahmad, 2014; Mahardhani, 2015)

Oleh karena itu Kepala Sekolah sebagai administrator pendidikan harus lebih banyak berfungsi sebagai koordinator pelaksanaan kurikulum di sekolahnya. Dengan kata lain, Kepala Sekolah harus memimpin semua staf yang ada di sekolah, agar dalam melaksanakan tugas dan fungsinya mengacu pada terlaksananya kurikulum.

Fungsi-fungsi manajemen pelaksanaan kurikulum harus menjadi landasan tugas utama Kepala Sekolah. Ia harus merencanakan secara seksama bagaimana kurikulum potensial dapat diwujudkan oleh para guru di sekolah. Ia berusaha mendorong dan memacu guru agar pelaksanaan kurikulum sesuai dengan ketentuan yang ada dalam GBPP. Ia juga harus mengorganisasi semua sumber yang diperlukan untuk menunjang pelaksanaan kurikulum. Ia harus menilai dan memantau pelaksanaan kurikulum di sekolahnya, agar dapat menentukan tingkat keberhasilan kurikulum di sekolah yang dipimpinnya (Sudjana, 1996).

\section{Tahap Perencanaan}

Perencanaan pada dasarnya adalah proyeksi tentang apa yang harus dilaksanakan. Dalam hubungannya dengan perencanaan pembinaan kurikulum, dimaksudkan adalah mengadakan proyeksi mengenai tindakan-tindakan pembinaan kurikulum. Dalam proyeksi ini diidentifikasi tujuan-tujuan pembinaan, strategi pembinaan, dan menilai keberhasilan pembinaan. Tujuan pembinaan didasarkan kepada target yang harus dicapai dari kurikulum, yakni terwujudnya kurikulum potensial atau GBPP melalui kegiatan atau proses pengajaran yang dilaksanakan guru. Indikator tampak dalam penyelesaian materi GBPP pada akhir semester dan kadar penguasaan materi oleh siswa (daya serap kurikulum). Strategi pembinaan ditentukan bersama antara Kepala Sekolah dan guru, yakni menentukan prosedur dan teknik mengoptimalkan kegiatan pengajaran, bimbingan penyuluhan, dan proses penilaian hasil belajar siswa. Sebelum rencana dilaksanakan Kepala Sekolah mengorganisasi semua potensi yang ada baik potensi tenaga, sarana, maupun dana. Adanya organisasi pelaksana pembinaan kurikulum dengan tugas dan tanggung jawabnya sangat diperlukan agar upaya pembinaan dapat dilaksanakan sesuai dengan rencana. Tim pelaksana pembinaan dipercayakan kepada guru, tim penilai, dan pemantau bisa ditunjuk wakil kepala sekolah (Tim Pengembang MKDP Kurikulum dan Pembelajaran,2006). 


\section{Tahap Pengorganisasian dan Koordinasi}

Pada tahap ini, kepala sekolah mengatur pembagian tugas mengajar, penyusunan jadwal pelajaran dan jadwal kegiatan ekstrakulikuler, sebagai berikut:

1. Pembagian tugas mengajar dan tugas lain perlu dilakukan secara merata, sesuai dengan bidang keahlian dan minat guru. Diupayakan setiap guru memperoleh jam tugas sesuai dengan beban tugas minimal. Pemerataan beban tugas akan menumbuhkan rasa kebersamaan. Pemberian tugas yang sesuai dengan keahlian dan minat akan meningkatkan motivasi kerja guru. Memperoleh tugas sesuai dengan beban minimal akan membuat guru merasa aman dan dapat naik pangkat dengan tepat waktu.

2. Penyusunan jadwal pelajaran diupayakan agar guru mengajar maksimal 5 hari/minggu, sehingga ada 1 hari tidak mengajar untuk pertemuan MGMP. Setiap hari sebaiknya guru tidak mengajar lebih dari 6 jam, sehingga ada waktu istirahat.

3. Penyusunan jadwal pola kegiatan perbaikan dan pengayaan secara normal setiap mata pelajaran akan memerlukan kegiatan perbaikan bagi siswa yang belum tuntas penugasan terhadap bahan ajar. Oleh karena itu, ketika menyusun jadwal pelajaran sudah harus dialokasikan waktu untuk kegiatan perbaikan bagi siswa yang belum tuntas dan pengayaan bagi yang sudah tuntas.

4. Penyusunan jadwal kegiatan ekstrakulikuler. Kegiatan ekstrakulikuler perlu difokuskan untuk mendukung kegiatan kurikuler dan kegiatan lain yang mengarah, pada pembentukan keimanan/ketakwaan, kepribadian, dan kepemimpinan dengan keterampilan tertentu.

5. Penyusunan jadwal penyegaran guru. Guru secara periodik perlu mendapatkan penyegaran tentang perkembangan iptek maupun metode mengajar. Penyegaran perlu dijadwalkan, dengan memanfaatkan waktu-waktu libur sekolah.

\section{Tahap Pelaksanaan}

Tugas utama kepala sekolah adalah melakukan supervisi, dengan tujuan untuk membantu guru menemukan dan mengatasi kesulitan yang dihadapi. Dengan cara itu guru akan merasa didampingi pimpinan, sehingga akan meningkatkan semangat kerjanya.

\section{Fungsi Kurikulum}

Dalam proses belajar jelas kedudukan kurikulum sangat penting, karena dengan kurikulum maka anak sebagai individu yang berkembang akan mendapatkan manfaat. Namun disamping anak maka kurikulum juga berfungsi bagi kepentingan-kepentingan yang lain (Soetopo \& Soemanto, 1986). 


\section{Fungsi Kurikulum Dalam Rangka Mencapai Tujuan Pendidikan}

Kurikulum suatu sekolah pada dasarnya merupakan suatu alat atau usaha untuk mencapai tujuan-tujuan pendidikan yang diinginkan oleh sekolah tertentu yang dianggap cukup tepat dan penting untuk dicapai, maka salah satu tindakan yang mungkin diambil adalah meninjau kembali tujuan yang selama ini digunakan oleh sekolah tersebut. Dengan kata lain, jika tujuan-tujuan yang diinginkan tidak tercapai, maka orang cenderung untuk meninjau kembali alat yang digunakan untuk mencapai tujuan tersebut, antara lain meninjau kurikulumnya. Jadi fungsi kurikulum di sini adalah sebagai alat atau jembatan untuk mencapai tujuan.

\section{Fungsi Kurikulum bagi Anak}

Kurikulum sebagai organisasi belajar tersusun, adalah disiapkan untuk anakanak/murid sebagai salah satu konsumsi pendidikan mereka. Dengan ini maka diharapkan mereka akan mendapat sejumlah pengalaman baru yang kelak kemudian hari dapat dikembangkan seirama dengan perkembangan anak, guna melengkapi bekal hidupnya.

\section{Fungsi Kurikulum bagi Guru}

Bagi guru kurikulum berfungsi sebagai:

a. Pedoman kerja dalam menyusun dan mengorganisir pengalaman belajar para anak didik.

b. Pedoman untuk mengadakan evaluasi terhadap perkembangan anak dalam rangka menyerap sejumlah pengalaman yang diberikan.

\section{Fungsi Kurikulum bagi Kepala Sekolah dan Pembina Sekolah}

Bahwa Kepala Sekolah sebagai seorang Administrator dan Supervisor juga mempunyai tanggung jawab dalam kurikulum. Oleh karena itu fungsi kurikulum bagi kepala sekolah dan para pembina lainnya adalah:

a. Sebagai pedoman dalam mengadakan fungsi supervisi yaitu memperbaiki situasi belajar.

b. Sebagai pedoman dalam melaksanakan fungsi supervisi dalam menciptakan situasi untuk menunjang situasi belajar anak ke arah yang lebih baik.

c. Sebagai pedoman dalam melaksanakan fungsi supervisi dalam memberikan bantuan kepada guru untuk memperbaiki situasi mengajar.

d. Sebagai seorang administrator maka kurikulum dapat dijadikan pedoman untuk memperkembangkan kurikulum lebih lanjut.

e. Sebagai pedoman untuk mengadakan evaluasi kemajuan belajar mengajar. 


\section{ANALISIS PERMASALAHAN}

Sebagaimana dijelaskan dalam teori dan berbagai sumber tentang administrai dan pembinaan kurikulum di sekolah bahwa pembinaan kurikulum yang menjadi tanggung jawab kepala sekolah antara lain adalah:

1. Pencapaian tujuan lembaga pendidikan / sekolah

2. Efektivitas dan efisiensi strategi pelaksanaan kurikulum

3. Efektivitas dan efisiensi penggunaan sarana kurikuler

4. Menilai keberhasilan upaya pembinaan kurikulum yang dilaksanakan staff

Ruang lingkup pembinaan kurikulum oleh guru mencakup antara lain:

1. Proses belajar mengajar atau hasil belajar

2. Pelaksanaan bimbingan penyuluhan

3. Pembinaan administrasi sekolah

4. Pembinaan pribadi

Berdasarkan hal di atas, maka banyak ditemukan ketidak sesuaian antara teori dan prakteknya di lapangan. Permasalahan-permasalahan yang ditemukan di lapangan seperti yang telah dikemukakan di atas perlu dikaji secara sungguh-sungguh agar dapat dicari berbagai alternatif pemecahan masalah untuk kemudian dipilih alternatif yang paling sesuai dan dievaluasi hasilnya. Adapun permasalahan-permasalahan yang penulis temukan adalah sebagai berikut:

1. Penyusunan jadwal yang sering diubah yang disebabkan karena banyak guru yang mengajar di tempat lain. Pihak sekolah harus menyesuaikan jadwal para guru terutama mereka yang mengajar di sekolah lain.

2. Tingkat absensi guru dan siswa cukup tinggi.

3. Guru jarang membuat perangkat pembelajaran karena kepala sekolah jarang memeriksanya.

4. Penempatan guru yang tidak tepat, banyak guru yang mengajar di luar bidang kemampuannya.

Permasalahan yang terjadi lebih banyak disebabkan oleh lemahnya Kepala Sekolah dan guru sebagai pelaksana kurikulum. Sebagai seorang pemimpin, Kepala Sekolah belum menjadikan kurikulum sebagai pedoman kerjanya. Seperti yang sudah diungkapkan di atas bahwa kurikulum berfungsi untuk Kepala Sekolah sebagai pedoman dalam mengadakan fungsi supervisi yaitu memperbaiki situasi belajar, sebagai pedoman dalam melaksanakan fungsi supervisi dalam menciptakan situasi untuk menunjang situasi belajar anak ke arah 
yang lebih baik, dan sebagai pedoman dalam melaksanakan fungsi supervisi dalam memberikan bantuan kepada guru untuk memperbaiki situasi mengajar.

Menjaga dan mempertahankan pelaksanaan kurikulum agar sesuai dengan tuntutan dan ketentuan yang telah ditetapkan dalam kurikulum potensial menjadi tugas dan tanggung jawab semua aparat pendidikan, seperti para pengawas, kepala sekolah, guru, dan tenaga kependidikan lainnya. Namun demikian upaya pembinaan kurikulum yang paling langsung adalah kepala sekolah dan guru. Itulah sebabnya jika Kepala Sekolah dan guru belum melaksanakan fungsinya dalam pembinaan kurikulum, maka proses belajar mengajar di sekolah tersebut akan terus mengalami kendala dan masalah yang akan mengakibatkan rendahnya mutu pendidikan di sekolah tersebut.

\section{Pemecahan Masalah}

Dari keempat masalah yang ada di SMA Tunas Baru Ciparay dapat disimpulkan bahwa inti permasalahan terletak pada kelemahan kepala sekolah dalam melaksanakan fungsinya, baik sebagai seorang pemimpin maupun sebagai manajer. Sebagai seorang pemimpin, kepala sekolah seharusnya mampu menunjuk orang yang tepat sesuai dengan kemampuannya. Berdasarkan pengamatan penulis, munculnya masalah-masalah tersebut sebagian penyebabnya adalah banyak pekerjaan yang dipegang oleh orang-orang yang tidak tepat. Untuk mengatasi masalah tersebut sebaiknya Kepala Sekolah harus bersikap profesional, tahu dan melaksanakan fungsinya sebagai pemimpin dan manajer dengan baik.

Seperti sudah diungkapkan di atas bahwa Peranan kepala sekolah dalam pembinaan kurikulum sangat menentukan keberhasilan penyelenggaraan pendidikan di sekolahnya. Bahkan dapat dikatakan Kepala Sekolah bertanggung jawab penuh terhadap penyelenggaraan pendidikan di sekolah. Pendidikan dikatakan berjalan apabila kurikulum potensial dilaksanakan di sekolah oleh semua staf, dan siswa yang terlibat di dalamnya. Oleh karena itu Kepala Sekolah sebagai administrator pendidikan harus lebih banyak berfungsi sebagai koordinator pelaksanaan kurikulum di sekolahnya. Dengan kata lain, Kepala Sekolah harus memimpin semua staf yang ada di sekolah, agar dalam melaksanakan tugas dan fungsinya mengacu pada terlaksananya kurikulum.

Walaupun demikian, masalah-masalah yang terjadi tidak hanya disebabkan karena kesalahan Kepala Sekolah sebagai seorang pemimpin. Tanggung jawab pembinaan kurikulum merupakan tanggung jawab semua pihak baik pelaksana kurikulum maupun tim pengembang kurikulum. Guru juga berperan penting dalam pelaksanaan pembinaan kurikulum yang akan berpengaruh juga terhadap proses belajar mengajar dikelas. 
Seperti sudah dijelaskan di atas bahwa ruang lingkup pembinaan kurikulum oleh guru salah satunya adalah proses belajar mengajar atau hasil belajar. Pembinaan proses belajar mengajar dilakukan oleh setiap guru. Aspek pembinaan mencakup penyusunan satuan pelajaran, pengadaan bahan-bahan pengajaran, strategi belajar mengajar, penilaian hasil belajar siswa, berdasarkan rambu-rambu yang ada dalam kurikulum potensial. Upaya pembinaan ini dilakukan setiap saat guru mengajar, sehingga kelemahan dan kekurangan dalam hal pengajaran dapat diperbaiki dari waktu ke waktu. Indikator keberhasilan pembinaan dilihat dari proses belajar dan hasil belajar yang dicapai siswa pada akhir pengajaran. Tetapi masalah yang terjadi di SMA Tunas Baru Ciparay adalah tingkat absensi guru yang cukup tinggi (karena banyak mengajar di tempat lain) dan guru yang jarang membuat perangkat pembelajaran, yang membuktikan bahwa pembinaan kurikulum oleh guru dalam hal proses belajar mengajar ternyata belum dilaksanakan dengan baik. Seringnya ketidakhadiran guru di kelas menyebabkan pembinaan proses belajar mengajar jarang dilakukan sehingga guru tidak dapat memperbaiki kelemahan dan kekurangannya dalam hal pengajaran.

Dalam hal ini, Kepala Sekolah sebagi supervisor pelaksanaan pembinaan kurikulum di sekolah sebaiknya mengambil tindakan:

1. Memberikan teladan yang baik bagi guru dan staf dalam hal kedisiplinan.

2. Memberikan sanksi bagi guru yang kurang disiplin.

3. Memberikan apresiasi/reward bagi guru yang disiplin.

4. Memberikan pembinaan bagi para guru baik secara formal maupun informal.

5. Menempatkan guru dan staf sesuai dengan kemampuannya (prinsip "the right man in the right place").

Jika Kepala Sekolah dan guru tidak berubah untuk melaksanakan fungsi pembinaan kurikulum dengan baik, maka dapat dipastikan bahwa sekolah tersebut tidak akan dapat berkembang secara kualitas maupun kuantitas, dan akan terus memiliki mutu yang rendah yang berakibat juga pada mutu peserta didik.

\section{KESIMPULAN}

Kita tahu bahwa dalam proses pendidikan, hasil yang diharapkan adalah berupa lulusan yang memiliki kemampuan untuk melaksanakan peran-perannya di masyarakat untuk masa yang akan datang. Setiap peserta didik yang telah melewati proses pendidikan di sekolah diharapkan dapat menjadi sumber daya manusia yang unggul, yang memiliki ketrampilan 
yang dibutuhkan dirinya, masyarakat, bangsa, dan negara sehingga dapat membangun dirinya, masyarakat, bangsa, dan negaranya.

Pertumbuhan dan perkembangan peserta didik bergantung pada dua unsur yang saling mempengaruhi, yakni bakat yang dimiliki peserta didik sejak lahir, dan lingkungan yang mempengaruhi hingga bakat itu tumbuh dan berkembang. Sekolah sebagai suatu lembaga pendidikan formal, secara sistematis merencanakan bermacam-macam lingkungan, yakni lingkungan pendidikan yang menyediakan berbagai kesempatan bagi peserta didik untuk melakukan berbagai kegiatan belajar. Dengan berbagai kesempatan belajar itu, pertumbuhan dan perkembangan peserta didik diarahkan dan didorong ke pencapaian tujuan yang dicita-citakan. Lingkungan tersebut disusun dan ditata dalam suatu kurikulum, yang pada gilirannya dilaksanakan dalam bentuk proses pembelajaran.

Walaupun pemerintah sudah menetapkan kurikulum nasional yang harus menjadi pedoman sekolah-sekolah dalam melaksanakan proses pembelajarannya, namun dalam pelaksanaannya tetap mengalami banyak kendala. Kendala yang utama adalah dalam proses pelaksanaan pembinaan kurikulum di sekolah-sekolah. Masalah ini juga penulis temui di SMA Tunas Baru Ciparay, yang mengalami kendala dalam pelaksanaan pembinaan kurikulum oleh Kepala Sekolah dan guru-guru.

Dari hasil pengamatan penulis dapat disimpulkan bahwa permasalahan yang terjadi lebih banyak disebabkan oleh lemahnya Kepala Sekolah dan guru sebagai pelaksana kurikulum. Seperti yang sudah diungkapkan dalam kajian pustaka bahwa kurikulum berfungsi bagi Kepala Sekolah sebagai pedoman dalam mengadakan fungsi supervisi yaitu memperbaiki situasi belajar, sebagai pedoman dalam melaksanakan fungsi supervisi dalam menciptakan situasi untuk menunjang situasi belajar anak ke arah yang lebih baik, dan sebagai pedoman dalam melaksanakan fungsi supervisi dalam memberikan bantuan kepada guru untuk memperbaiki situasi mengajar. Namun sebagai seorang pemimpin, Kepala Sekolah belum menjadikan kurikulum sebagai pedoman kerjanya.

Walaupun demikian, masalah-masalah yang terjadi tidak hanya disebabkan karena kesalahan Kepala Sekolah sebagai seorang pemimpin. Tanggung jawab pembinaan kurikulum merupakan tanggung jawab semua pihak baik pelaksana kurikulum maupun tim pengembang kurikulum. Guru juga berperan penting dalam pelaksanaan pembinaan kurikulum yang akan berpengaruh juga terhadap proses belajar mengajar dikelas.

Menjaga dan mempertahankan pelaksanaan kurikulum agar sesuai dengan tuntutan dan ketentuan yang telah ditetapkan dalam kurikulum potensial menjadi tugas dan 
tanggung jawab semua aparat pendidikan, seperti para pengawas, kepala sekolah, guru, dan tenaga kependidikan lainnya. Namun demikian upaya pembinaan kurikulum yang paling langsung adalah kepala sekolah dan guru. Itulah sebabnya jika Kepala Sekolah dan guru belum melaksanakan fungsinya dalam pembinaan kurikulum, maka proses belajar mengajar di sekolah tersebut akan terus mengalami kendala dan masalah yang akan mengakibatkan rendahnya mutu pendidikan di sekolah tersebut.

Penulis berharap dari penulisan ini pihak sekolah terutama Kepala Sekolah sebagai pengambil kebijakan di sekolah, dapat segera mengambil tindakan-tindakan penting yang berkaitan dengan pembinaan kurikulum. Penanganan masalah dengan segera dan tepat dapat membuat proses belajar mengajar dapat berjalan kembali dengan baik dan dapat mencapai tujuan pendidikan yang diharapkan. Dengan berjalannya kembali pembinaan kurikulum oleh Kepala Sekolah dan guru-guru di SMA Tunas Baru Ciparay maka pasti akan ada peningkatan mutu sekolah yang akan berakibat juga pada meningkatnya kuantitas murid di sekolah tersebut.

\section{DAFTAR PUSTAKA}

Ahmad, S. (2014). Problematika Kurikulum 2013 Dan Kepemimpinan Instruksional Kepala Sekolah. Jurnal Pencerahan, 8(2), 98-108. http://doi.org/10.13170/JP.8.2.2158

Cropley, A. J., \& Dave, R. H. (2014). Lifelong education and the training of teachers: developing a curriculum for teacher education on the basis of the principles of lifelong education (Vol. 5). Elsevier

Farisi, M. I. (2011). Guru sebagai pengembang kurikulum pendidikan multikultur: Tinjauan dari Perspektif Epistemologis. Temu Ilmiah Nasional Guru III, (November), 1-13. Retrieved from http://utsurabaya.files.wordpress.com/2012/07/ting-iiia.pdf

Hamalik, O. (1995). Kurikulum dan Pembelajaran. Jakarta: Bumi Aksara

Mahardhani, A. J. (2015). Kepemimpinan Ideal Kepala Sekolah. Jurnal Dimensi Pendidikan Dan Pembelajaran, 3(2), 1-4.

Prihantoro, C. R. (2015). The perspective of curriculum in Indonesia on environmental education. International Journal of Research Studies in Education, 4(1), 77-83. http://doi.org/10.5861/ijrse.2014.915

Sanjaya, Wina.(2008). Kurikulum dan Pembelajaran. Jakarta: Prenada Media Grup

Soetopo, H., \& Soemanto, W. (1986). Pembinaan dan Pengembangan Kurikulum Sebagai Substansi Problem Administrasi Pendidikan. Jakarta: Bumi Aksara. 
Sudjana, N. (1996). Pembinaan dan Pengembangan Kurikulum di Sekolah. Bandung: Sinar Baru Algensindo.

Tim Dosen Jurusan Administrasi Pendidikan. (2007). Pengelolaan Pendidikan. Jurusan Administrasi Pendidikan Universitas Pendidikan Indonesia, Bandung.

Tim Pengembang MKDP Kurikulum dan Pembelajaran. (2006). Kurikulum Pembelajaran. Jurusan Kurikulum dan Teknologi Pendidikan. Bandung: UPI Bandung.

Tyler, Ralph.W.(2013). Basic principles of curriculum and instruction. Chicago: The University of Chicago Press. 